\title{
Artigo
}

\section{The 2008 financial crisis and the Renminbi internationalization}

\author{
A crise financeira de 2008 e a internacionalizaçâo do Renminbi
}

Ana Tereza Lopes Marra de Sousa ${ }^{3}$

William Daldegan de Freitas ${ }^{4}$

DOI: $10.5752 /$ P.1809-6182.2018v15.n2.p33

Recebido em: 06 de agosto de 2018 Aprovado em: 18 de outubro de 2018

\begin{abstract}
In this work, we investigated the RMB internationalization policy. We have argued that from the 2008 crisis onwards, the policy not only aimed to accelerate China's financial liberalization, but also took the responsibility of boosting foreign trade, facilitating the export of capital and increasing China's economic influence in the world.
\end{abstract}

Key-words: Renminbi internationalization; 2008 crisis; International monetary system

\section{Resumo}

Neste trabalho, investiga-se a politica de internacionalização do RMB. Argumenta-se que da crise 2008 em diante, essa politica não objetivou apenas acelerar a liberalização financeira da China, mas também assumiu a responsabilidade de impulsionar o comércio exterior, facilitar exportação de capital e aumentar a influência econômica da China no mundo.

Palavras-chave: Internacionalização do RMB; crise de 2008; sistema monetário nternacional

\footnotetext{
3. Doutora em Relações Internacionais pelo Programa de Pós-Graduação em Relaçóes Internacionais San Tiago Dantas (Unesp/Unicamp/PUCSP) , Professora Adjunta do curso de Relaçóes Internacionais da UFABC. ORCID: 0000-0002-7580-4797

4. Doutorando no Programa de Pós-Graduação em Relaçôes Internacionais San Tiago Dantas (Unesp/Unicamp/ PUCSP), Mestre em Relações Internacionais pela PUC Minas, Professor da Escola de Negócios e Hospitalidade da Universidade Anhembi Morumbi. ORCID: 0000-0001-5806-0557
} 


\section{Introduction}

China's ascension in international relations in the last decades along with the efforts to internationalize its currency, the Renminbi (RMB), after 2008 financial crisis, has raised questions of whether there is an emergence of new geopolitics in the financial and monetary system ${ }^{5}$. Although the Dollar is still the most widely used currency, there is a nascent interest in understanding the RMB internationalization policy due to importance that currencies have had historically as an element for the construction of great powers.

In this work, we investigated the RMB internationalization. We have argued that the 2008 crisis had an important role to change the parameters of RMB internationalization policy. In the early 2000s that policy was pursued as an instrument to accelerate China's financial liberalization, but from the 2008 crisis onwards, the policy also took the responsibility of boosting Chinese foreign trade, facilitating the export of capital and increasing China's economic influence in the world. We have interpreted that the goal of the internationalization policy is not for RMB to replace the Dollar's role, but to route a future in which Chinass financial and monetary influence in the world will be bigger, making the country less dependent of United States (US) currency and financial system.

In addition to this introduction, the paper has three more sections. In the second, we discuss the recent process of RMB internationalization. In the third, we point out to direct mechanisms used by Chinese government to facilitate the international use of RMB and the results achieved by the internationalization policy. In the fourth, we present our conclusions.

5. As an example of this type of questioning, see the anthology series organized in 2018 by "Foreign Affairs" to debate if there was an emergence of a new financial geopolitics (COUNCIL ON FOREIGN RELATIONS, 2018). The review can be consulted in https://www.foreignaffairs.com/anthologies/2018-01-22/new-financial-geopolitics.

\section{The RMB internationalization: not only an instrument for domestic financial reform}

Since 2003 the Chinese government has developed a more permissive policy for RMB internationalization by allowing the Monetary Authority of Hong Kong to conduct business in RMB (KROEBER, 2013). This first movement of RMB internationalization is widely interpreted as a means of agents within the Chinese government to push towards a greater financial liberalization of China (KROEBER, 2013; LIAO \& MCDOWELL, 2014). This would happen from the creation of the offshore RMB market in Hong Kong, due the result of an onshore and offshore segregation in the RMB market, over time, arbitrage policies would be implemented, forcing an equalization of prices, which would mean abolition of capital controls (KROEBER, 2013, p.24; PARK, 2016; LIAO \& MCDOWELL, 2014).

With the 2008 crisis, the goal of using the internationalization of the RMB for financial reform remained, however was noticeable that such a process was not only seen as a tool of reform, but also as having other purposes. Chinese authorities increased concerns about the domain of the international monetary system by a single currency, the Dollar. Zhou Xiaochuan, governor of the People's Bank of China (PBC), pointed out to the growing impossibility of reconciling demands for global stability and economic growth with the interests of US monetary policy (ZHOU, 2009, p.1). Chinese authorities reinforced the interpretation that the monetary and financial system, perceived as hierarchical and unequal systems, with "exorbitant privileges" for the Dollar, could disrupt the era of "peace and development" advocated by China (PARK, 2016, KROEBER, 2013, COHEN, 2017). 
By then, China has begun to incorporate a perspective from which interprets that the RMB internationalization is desirable given the unfeasibility of maintaining a long-term system in a single currency (ZHANG \& TAO, 2014, GAO, 2010). Such a view would not allow the RMB to replace the Dollar, given the very composition of Chinese reserves and the destabilizing global effects of a Dollar shock. However, the Chinese authorities started working with the idea that alongside the Euro, the Dollar and a renewed role for Special Drawing Rights (SDR), the RMB could contribute to establish a more stable and multipolar international monetary system (ZHANG \& TAO, 2014; GAO, 2010; KROEBER, 2013).

Such a notion about the role of the Chinese currency is supported by defense of multipolarity on foreign policy (ZHANG \& TAO, 2014; GAO, 2010). As Deng (2008, p.45) states, China prefers a "more democratic pluralistic world where a set of values does not become a single standard; [...] and a single power cannot dictate world affairs". In the long term, the country seeks three objectives: to preserve the internal order and the well-being of its population; to defend itself against external threats to its sovereignty and integrity, and; obtain and maintain China's influence as a prominent state in interna- tional relations - the three objectives are set out in China’s 2002 White Paper on National Defense.

In order to achieve these goals, stability is an important element (MASUDA, 2009; DENG, 2008; SU, 2009). However, the monetary policy of the Quantitative Easing implemented by FED after the crisis, with the potential to devalue the Dollar, cause inflation and reduce China's international reserves, made the country aware of the "Dollar Trap" it was involved in (KRUGMAN, 2009). In addition, the illiquidity of the financial markets, which contributed to the decline in trade, highlighted China's dependence of Wall Street's coordinated financial system.

It was in this context, that Chinese government tried to reinforce country's influence in the governance of the financial and monetary system (PARK, 2016, KROEBER, 2013, COHEN, 2017). Besides participating in G20 and fighting to increase its voting power in the International Monetary Fund (IMF), the country developed other initiatives to deal with the shortcomings of the economic system and additionally expand its international influence. Chart 1 highlights some of these actions; one of them was the promotion of RMB internationalization. In fact, after 2008 crisis, China has seen a window of opportunity to accelerate the construction of a more multi-polar world.

\section{Chort 1 - Actions to reinforce China's economic influence}

i) the intensification of "Go Global" policy for internationalization of companies;

ii) the establishment of more Free Trade Agreements (FTAs) and Comprehensive Economic Partnership Agreements (CEPAs) with diverse countries;

iii) the constitution of Chiang Mai Initiative Multilateralization (CMIM) Agreement of Association of Southeast Asian Nations (ASEAN) + 3 (China, Japan and South Korea);

iv) the opening of the New Development Bank (NBD) and the establishment of the Reserve Contingent Arrangement within BRICS;

v) the constitution of the Asian Infrastructure Investment Bank (AIIB);

vi) the intensification of internationalization of Chinese banks;

vii) the launch of One Belt, One Road Initiative (B\&R), and;

viii) the promotion of $\mathrm{RMB}$ internationalization. 
More than leading China's financial reform, the RMB internationalization would serve as a policy to expand economic influence of the country, to protect and boost Chinese exports and investments. In the view of Park (2016), thought together, Chinese actions aims to accelerate the organization of a more multipolar international financial and monetary system, with less dependence on the dollar and Wall Street institutions. The Chinese interpretation is that the monetary system currently dominated by the Dollar, as the then President $\mathrm{Hu}$ Jintao said, is a "product of the past," and the internationalization of the RMB, although "a fairly long process", is directly linked to the update the world needs (BBC NEWS, 2011).

\section{Direct mechanisms for RMB internationalization and results}

From 2008 onwards, direct mechanisms to promote the internationalization of RMB were implemented, which reinforces our interpretation that after 2008 crisis this policy is no longer only a mean for financial domestic reform. As we present below, RMB internationalization policy took the responsibility of boosting Chinese foreign trade and facilitating the export of capital. In addition, along with other actions cited in Chart 1, that policy intends to route a future in which China's financial and monetary influence in the world will be bigger.

In 2008 China developed the "Cross-border Trade RMB Settlement Pilot Project", which allowed selected companies in five cities, which accounted for about $40 \%$ of Chinese exports, to negotiate and settle their transactions in RMB with Hong Kong, Macao and the ASEAN countries (HONG KONG MONETARY AUTHORITY, 2009). In 2010, this program was expanded and in 2011 began to cover the whole country. In addition, from 2012 onwards, all importers and exporters based in China were allowed to settle their foreign trade operations in RMB (PARK, 2016; HUANG, WANG \& FAN, 2014 KROEBER, 2013).

Such measures facilitated the use of currency as a medium of exchange, mainly in Asia. SWIFT data pointed out that in 2015 the RMB became the most used currency in Asia to make payments to China and Hong Kong, between April 2012 and 2015 the weight of the RMB as a means of payment grew by $327 \%$ in China/Hong Kong and Asia transactions (TREASURY MANAGEMENT INTERNATIONAL, 2015).

These measures were accompanied by incentives for the currency to also be used for external investment. PBC launched in 2011 the "Pilot Program of RMB Settlement for Overseas Direct Investment", which allowed domestic companies that had the approval to make Foreign Direct Investment (FDI) to do so in RMB (PEOPLE'S BANK OF CHINA, 2011). Such measures reinforce the prospect of using the internationalization of currency as a way of reducing transaction costs, which would have the function of protecting Chinese investors and boosting the export of capital.

In addition, to facilitate the settlement of trade and investment in RMB, the Chinese government has adopted Bilateral Swap Agreements (BSAs). Originally, BSAs are tools to help countries in liquidity crises. However, since 2008, PBC has used them as a method to promote trade and bilateral investment in local currencies (KROEBER, 2013). The BSAs were the way China found to deal with the retreat of foreign trade after the crisis, providing liquidity alternatives to importers of Chinese products. Currently, China is estimated to have conducted BSAs with more than 30 countries, totaling about 3.33 trillion yuan (BLOOMBERG NEWS, 2017). While it is still unclear which BSAs contracts have actually been drawn, they demonstrate China's financial strength in the world (LIAO \& MCDOWELL, 2014). 
Another action to facilitate the use of the RMB was the expansion of the RMB Clearing Bank network abroad, considered necessary to amplify the geographical diversification of the currency use and increase its liquidity (PARK, 2016). In recent years, this network has grown regionally and globally, notably with the authorization given in February 2018 for JP Morgan to take over the role of RMB Clearinghouse in the US (REUTERS, 2018).

Another measure aimed at facilitating the use of the RMB was the establishment in 2015 of an interbank payment system, the China International Payment System (CIPS). CIPS is a settlement system that provides a format similar to other international payment systems. In 2017, a second phase of CIPS was launched to facilitate the use of the $\mathrm{RMB}$ in the $\mathrm{B} \& \mathrm{R}$ Initiative and to push the transformation of Shanghai into a financial center. Official data show that CIPS is currently used by about 85 countries to make payments in RMB (XINHUANET, 2017).

Another measure that has a direct impact on the internationalization of the RMB (although it represents much more than that) was the inclusion of the currency in the basket that composes the value of the IMF's SDR. For the inclusion, the IMF took into account two criteria: i) the participation of the country in world exports, and ii) if the currency was "freely usable" (INTERNATIONAL MONETARY FUND - IMF, 2017a). While the first criterion was indisputably met, the second was debatable, because China does not have an open financial market for foreign investors to freely trade assets in RMB, once the capital account is still considered to be relatively closed. The IMF's decision to even include the RMB in the SDR basket would have been mostly political, a way the IMF has found to increase the pressure on China's financial liberalization, as Park points out (2016, p.80), "as a strong incentive for China to commit to acceler- ating its financial reforms and the opening of the capital market."

In addition to expressing an endorsement for the internationalization of the currency, the inclusion of the RMB in the SDR basket would carry even deeper meanings: i) because it meant greater international acceptance from China, it would be a form of recognition that the country has followed the right path reforms; ii) represents geopolitical gains, since the relative weight of other currencies has decreased; iii) helps to accelerate the transformation of the monetary system towards multipolarity (PARK, 2016).

With the internationalization of the RMB, China is expected to achieve benefits, such as: reducing transaction costs and risks, seigniorage, improving international status/soft power gain, greater resistance to external shocks, greater macroeconomic flexibility and influence on the international economy, and less dependence on the Dollar (ZHANG \& TAO, 2014, CHEN \& PENG, 2010, BA et al., 2010, HAI \& YAO, 2010). However, the overall results of this RMB internationalization initiative can still be considered very timid.

Regarding the use of the RMB as a reserve currency, despite the fact that the European Central Bank and a number of Asian countries, such as Indonesia and Australia, have started to save RMB, according to IMF data (2017b), of a total reserve of US\$ 7,900.63 billion, the RMB is accounting for about $1 \%$ of the total, behind the Dollar, Euro, Pound, Yen, Canadian and Australian Dollar. As for its use as a unit of account, some authors have pointed out a greater role for the RMB within the baskets of currencies that guide the exchange of East Asian countries (SHU, 2010; EICHENGREEN \& LOMBARDI, 2015), however no study is still conclusive given the very weight that the Dollar has in the basket of currencies that guides the Chinese exchange rate. 
As for the use of the RMB as a medium of exchange, considering the productive integration between China and the Asian countries, as well as the magnitude of financial and commercial flows between them, Eichengreen \& Lombardi (2015) see the possibility for RMB to emerge as a regional currency. The fact that China participates in various institutional arrangements in the region ${ }^{6}$ and have a trade deficit with most of the Asian countries could additionally strengthen the use of RMB (EICHENGREEN \& LOMBARDI, 2015). According to SWIFT (2015) data, Taiwan and countries like South Korea and Singapore adopt the RMB for most of their payments to China, while in countries like Malaysia and Australia this adoption has been growing. The use of RMB as a medium of exchange should also lead over time to the strengthening of other functions (reserve currency and unit of account) in the region.

But if the prospects for RMB in Asia seem positive, the data compiled from SWIFT (2018) reports shows that the currency global share is still low, in January 2018 it was only 1,66\%, although it has evolved between 2010-2018 from 17th to 5th position as the currency most used for payment. One of the reasons pointed out by researchers to explain the low share is that, despite the official discourse to the contrary, China has had resistance to advance in the convertibility of the capital account. It seems to be consensual in the literature the idea that the opening of the capital account is a necessary step for processes of internationalization of currencies (PARK, 2016; BA et al., 2010; ZHANG \& TAO, 2014; CHEN \& PENG, 2010; LI \& LIU, 2010). This poses a major domestic challenge for China, since such action could diminish the effec-

6. As an example of regional arrangements where there is Chinese participation and where there may be demand for the use of the RMB, one can cite the B\&R Initiative, the Chiang Mai Initiative Multilateralisation (CMIM) Agreement of ASEAN + 3 and the Asian Infrastructure Investment Bank (AIIB). tiveness of monetary policy, a play that has been essential to China’s economic policy effectiveness.

\section{Conclusion}

China's efforts to internationalize RMB after 2008 financial crisis, as we have shown, should be seen not only as a means to pursue domestic financial reform, but also as a way of boosting foreign trade, facilitating the export of capital and increasing China's economic influence in the world. The 2008 crisis was a turning point in the internationalization policy of the RMB. After that, the Chinese government saw a window of opportunity to start chasing an active policy in order to accelerate the creation of a more multipolar world. It is in this context that we should interpret the RMB internationalization policy, as a new means for China to deal with the shortcomings of the international economic system, the dependence of the Dollar and the US financial system. Ultimately, RMB internationalization aims to contribute for a multipolar monetary system and reinforces China's rise with renewed autonomy.

\section{References}

BA, Shusong et al. Effects of RMB internationalization on China's finance industry. In: PENG, Wensheng; SHU, Chang. Currency Internationalization: Global Experiences and Implications for the Renminbi. Palgrave Macmillan: London, 2010.

BBC NEWS. China's Hu Jintao: Currency system is 'product of past'. 17 January 2011. Disponível em <http://www.bbc. com/news/world-asia-pacific-12203391> Acesso em $18 \mathrm{fev}$. 2018. 361-371.

BLOOMBERG NEWS. China’s \$500 Billion Lifeline Swaps Cash for World-Wide Clout. 6 de junho de 2017. Disponível em <https://www.bloomberg.com/news/articles/2017-06-06/ china-s-500-billion-lifeline-swaps-cash-for-world-wide-clout> Acesso em 15 fev. 2018.

CHEN, Hongyi; PENG, Wensheng. The potential of the renminbi as na international currency. In: PENG, Wensheng; SHU, Chang. Currency Internationalization: Global Ex- 
periences and Implications for the Renminbi. Palgrave Macmillan: London, 2010.

COHEN, Benjamin J. Renminbi Internationalization: A Conflict of Statecrafts. International Economics Department. Chatam House, The Royal Institute of International Affairs. March 2017. COUNCIL ON FOREIGN RELATIONS. Foreign Affairs: A New Financial Geopolitics? The U.S-Led Monetary Order in a Tima of Turbulence. In: Foreign Affairs Anthology Series. Jan-2018. Disponível em < https://www.foreignaffairs.com/ anthologies/2018-01-22/new-financial-geopolitics> Acesso em 23 mar. 2018

DENG, Y. China's Struggle for Status: the realignment of international relations. Cambridge University Press: New York, 2008.

EICHENGREEN, Barry; LOMBARDI, Domenico. RMBI or RMBR: Is the Renminbi Destined to Become a Global or Regional Currency? NBER Working Paper No. 21716. November 2015.

FUNDO MONETÁRIO INTERNACIONAL. Review of the Special Drawing Right (SDR) Currency Basket. October 13, 2017(a). Disponível em <https://www.imf.org/en/ About/Factsheets/Sheets/2016/08/02/19/35/Review-of-the-Special-Drawing-Right-SDR-Currency-Basket> Acesso em 10 jan 2018.

FUNDO MONETÁRIO INTERNACIONAL. IMF Releases Data on the Currency Composition of Foreign Exchange Reserves Including Holdings in Renminbi. March 31, 2017 (b). Disponível em <http://www.imf.org/en/News/Articles/2017/03/31/pr17108-IMF-Releases-Data-on-the-Currency-Composition-of-Foreign-Exchange-Reserves> Acesso em 25 fev. 2018.

GAO, Haihong. Internationalization of renminbi and its implications for monetary policy. In: PENG, Wensheng; SHU, Chang. Currency Internationalization: Global Experiences and Implications for the Renminbi. Palgrave Macmillan: London, 2010.

HAI, Wen; YAO, Hongxin. Pros and Cons of international use of RMB for China. In: PENG, Wensheng; SHU, Chang. Currency Internationalization: Global Experiences and Implications for the Renminbi. Palgrave Macmillan: London, 2010.

HONG KONG MONETARY AUTHORITY. Renminbi trade settlement pilot scheme. External Department. SEPTEMBER 2009. Disponível em <http://www.hkma.gov. $\mathrm{hk} /$ media/eng/publication-and-research/quarterly-bulletin/ qb200909/fa2_print.pdf> Acesso em 22 fev. 2018.

HUANG, Yiping; WANG, Daili; FAN, Gang. Paths to a reserve currency: internationalization of the Renminbi and its implications. ABDI Working Paper Series. No 482, May 2014. KROEBER, Arthur. China's global currency: lever for financial reform. Brookings-Tsinghua Center for Policy Monograph Series, Number 3, February 2013.
KRUGMAN, Paul. China's Dollar Trap. In: The New York Times, April 2, 2009. Disponível em <http://www.nytimes. com/2009/04/03/opinion/03krugman.html?_r=0> Acesso em 10 jun 2017.

LI, David D; LIU, Linlin. RMB internationalization: empirical and policy analysis. In: PENG, Wensheng; SHU, Chang. Currency Internationalization: Global Experiences and Implications for the Renminbi. Palgrave Macmillan: London, 2010.

LIAO, Steven; MCDOWELL, Daniel. Redback Rising: China's Bilateral Swap Agreements and Renminbi Internationalization. In: International Studies Quarterly (2014) 1-20.

MASUDA, M. China's Search for a New Foreign Policy Frontier: Concept and Practice of "Harmonious World". In: China's Shift: Global Strategy of the Rising Power. NIDS JOINT RESEARCH SERIES No. 3, 2009.

PARK, Hyo-Sung. China's RMB Internationalization Strategy: Its Rationales, State of Play, Prospects and Implications. M-RCBG Associate Working Paper Series | No. 63. August 2016.

PEOPLE'S BANK OF CHINA. Pilot Program of RMB Settlement for Overseas Direct Investment to Support Chinese Enterprises to Go abroad. 30/01/ 2011. Disponível em <http://www.pbc.gov.cn/english/130721/2850129/index. html> Acesso em 25 fev. 2018.

REUTERS. China names JPMorgan Chase as yuan clearing bank in U.S. February 13, 2018. Disponível em <https:// www.reuters.com/article/us-china-us-yuan-clearing/china-names-jpmorgan-chase-as-yuan-clearing-bank-in-u-s-idUSKBN1FX0T0> Acesso em 25 fev. 2018.

SHU, Chang. Impacto $f$ renminbi Exchange rate on Asian Currencies. In: PENG, Wensheng; SHU, Chang. Currency Internationalization: Global Experiences and Implications for the Renminbi. Palgrave Macmillan: London, 2010.

SU, H. Harmonious World: The Conceived International Order in Framework of China's Foreign Affairs. In: China's Shift: Global Strategy of the Rising Power. NIDS JOINT RESEARCH SERIES No. 3, 2009.

SWIFT. Renminbi's stellar ascencion: are you on top of it? RMB Tracker, Sibos 2015 edition. Disponível em <https:// www.swift.com/our-solutions/compliance-and-shared-services/ business-intelligence/renminbi/rmb-tracker/document-centre?sort_by=field_date_value\&page=1 $>$ Acesso em 10 dez. 2017 .

SWIFT. RMB internationalisation: Where we are and what we can expect in 2018. RMB Tracker, January 2018. Disponível em <https://www.swift.com/our-solutions/compliance-and-shared-services/business-intelligence/renminbi/rmb-tracker/ document-centre> Acesso em 15 fev. 2018.

TREASURY MANAGEMENT INTERNATIONAL. SWIFT RMB Tracker: RMB \# 1 currency used in Asia Pacific with Greater China. 28th May 2015. Disponível em <https:// www.treasury-management.com/news/508/swift-rmb-tracker-rmb-1-currency-used-in-asia-pacific-with-greater-chinahtml> Acesso em 22 fev. 2018 
XINHUANET. China to launch 2nd phase of cross-border interbank payment system for RMB. 21/06/2017. Disponível em <http://www.xinhuanet.com/english/ 2017-06/21/c_136384061.htm> Acesso em 20 fev. 2018.

ZHANG, Liqing; TAO, Kunyu. The benefits ans costs of Renminbi internationalization. ABDI Working Paper Series No 481, may 2014.

ZHOU, Xiaochuan. Reform the international monetary system. Essay by Dr Zhou Xiaochuan, Governor of the People's Bank of China, 23 March 2009. Disponível em <https://www. bis.org/review/r090402c.pdf> Acesso em 15 jun. 2017. 